\title{
Antiproliferative effects of the GnRH antagonist cetrorelix and of GnRH-II on human endometrial and ovarian cancer cells are not mediated through the GnRH type I receptor
}

\author{
Carsten Gründker, Lars Schlotawa, Volker Viereck, Nicola Eicke, Anika Horst, Britta Kairies and Günter Emons \\ Department of Gynecology and Obstetrics, Georg-August-University, D-37070 Göttingen, Germany
}

(Correspondence should be addressed to G Emons; Email: emons@med.uni-goettingen.de)

\begin{abstract}
Background: The majority of human endometrial and ovarian cancer cell lines express receptors for GnRH. Their proliferation is time- and dose-dependently reduced by GnRH-I and its superagonistic analogues. Recently, we have demonstrated that, in human endometrial and ovarian cancer cell lines except for the ovarian cancer cell line EFO-27, the GnRH-I antagonist cetrorelix has antiproliferative effects comparable to those of GnRH-I agonists, indicating that the dichotomy between GnRH-I agonists and antagonists might not apply to the GnRH system in cancer cells. We were also able to show that the proliferation of human endometrial and ovarian cancer cells was doseand time-dependently reduced by GnRH-II to a greater extent than by GnRH-I agonists.

Objective: In this study we have assessed whether or not the antiproliferative effects of the GnRH-I antagonist cetrorelix in endometrial and ovarian cancer cells are mediated through the GnRH-I receptor.

Methods: We analysed the antiproliferative effects of the GnRH-I agonist triptorelin, the GnRH-I antagonist cetrorelix and GnRH-II in a panel of endometrial and ovarian cancer cell lines expressing GnRHI receptors, in the SK-OV-3 ovarian cancer cell line that does not express GnRH-I receptors, and in four GnRH-I receptor positive GnRH-I receptor knockout cell lines.

Results: We found that, after knockout of the GnRH-I receptor, the antiproliferative effects of the GnRH-I agonist triptorelin were abrogated, whereas those of the GnRH-I antagonist cetrorelix and of GnRH-II persisted.

Conclusions: These data suggest that, in endometrial and ovarian cancer cells, the antiproliferative effects of cetrorelix and of GnRH-II are not mediated through the GnRH-I receptor.
\end{abstract}

European Journal of Endocrinology 151 141-149

\section{Introduction}

The expression of gonadotropin-releasing hormone (GnRH, GnRH-I) and its receptor as a part of a negative autocrine/paracrine regulatory system of cell proliferation has been demonstrated in a number of human malignant tumours, including cancers of the endometrium, ovary and breast (1). In these cancers the in vitro proliferation can be inhibited by agonistic or antagonistic analogues of GnRH-I in a dose- and time-dependent manner (1-5). The dichotomy between GnRH-I agonists and antagonists as defined in pituitary gonadotrophs might not apply to the GnRH system in cancer cells. The mechanism by which GnRH-I antagonists work remains unknown.

Recently, we were able to show that GnRH type II (GnRH-II) has antiproliferative effects on these tumour cells that are significantly greater than those of the superactive GnRH-I agonist, triptorelin (6).
In the ovarian cancer cell line SK-OV-3, which does not express GnRH-I receptors (7), triptorelin had no effects on cell proliferation (7), whereas the GnRH-I antagonist cetrorelix had strong antiproliferative effects. These findings suggest that the antiproliferative effects of the GnRH-I antagonist cetrorelix are not attributable to a cross reaction with the GnRH-I receptor. Choi et al. (8) have reported that GnRH-II, is expressed in normal neoplastic ovarian surface epithelial cells and in cancers derived from these cells. In addition, they showed that, in immortalized ovarian surface epithelial cells, GnRH-II had antiproliferative effects (8). It might be speculated that, in addition to the autocrine GnRH-I system, an additional autocrine system based on GnRH exists in human cancers.

Millar et al. (9) have recently reported that the GnRH-I antagonist 135-18 has agonistic effects on the marmoset type II GnRH receptor transfected into COS-7 cells. As we have shown in human endometrial 
and ovarian cancers that a putative GnRH-II receptor could be present (6), this might explain why the GnRH-I antagonist cetrorelix behaves like an agonist in reproductive tissue tumours $(2-5)$.

In this study we have assessed whether or not the antiproliferative effects of the GnRH-I antagonist cetrorelix in endometrial and ovarian cancer cells are mediated through the GnRH-I receptor. For this purpose, we analysed the antiproliferative effects of the GnRH-I agonist triptorelin, the GnRH-I antagonist cetrorelix and of GnRH-II in a panel of endometrial and ovarian cancer cell lines expressing GnRH-I receptors, in the SK-OV-3 ovarian cancer cell line that does not express GnRH-I receptors, and in four GnRH-I receptor positive cell lines in which we knocked out the GnRH-I receptor.

\section{Materials and methods}

\section{Cell lines and culture conditions}

The human endometrial cancer cell lines Ishikawa, HEC-1A and Hec-1B and the ovarian cancer cell lines EFO-21, EFO-27, OVCAR-3, SK-OV-3 and BG-1 were obtained from American Type Culture Collection (ATCC, Manassas, Virginia, USA) or the sources detailed previously $(2,3)$. The cells were cultured at $37^{\circ} \mathrm{C}$ in a humidified atmosphere of $5 \% \mathrm{CO}_{2}$ in air as described previously $(2-4)$.

\section{GnRH analogues}

The GnRH-I antagonist cetrorelix (SB-75; [Ac-D$\mathrm{Nal}(2)^{1}$, D-Phe $(4 \mathrm{Cl})^{2}$, D-Pal $(3)^{3}$, D-Cit $^{6}$, D-Ala $\left.{ }^{10}\right] \mathrm{GnRH}-$ I) was kindly provided by Zentaris (Frankfurt, Germany) and the GnRH-I agonist [D-Trp $\left.{ }^{6}\right] \mathrm{GnRH}$ (triptorelin; pGlu-His-Trp-Ser-Tyr-D-Trp-Leu-Arg-Pro-Gly$\mathrm{NH}_{2}$ ) was kindly provided by Ferring Pharmaceuticals (Copenhagen, Denmark). Human GnRH-II ( $p$ Glu-HisTrp-Ser-His-Gly-Trp-Tyr-Pro-Gly- $\mathrm{NH}_{2}$ ) was purchased from Bachem (Heidelberg, Germany).

\section{Isolation of mRNA and cDNA synthesis}

Polyadenylated RNA [poly(A) mRNA] was prepared from cells grown in monolayer using the Oligotex direct mRNA kit (Qiagen, Hilden, Germany). The concentration of poly (A) mRNA in each sample was determined by photospectrometry. First-strand cDNA was generated by reverse transcription of $1 \mu \mathrm{g}$ poly(A) mRNA using $\mathrm{p}(\mathrm{dT})_{15}$ primers (Roche Diagnostics, Mannheim, Germany) with MMLV-reverse transcriptase according to the instructions of the suppliers (Life Technologies, Karlsruhe, Germany).

\section{PCR amplification}

The cDNAs $(2 \mathrm{ng})$ were amplified in a $50 \mu$ l reaction volume containing $10 \mathrm{mmol} / \mathrm{l}$ Tris-HCl (pH 8.3), $50 \mathrm{mmol} / \mathrm{l}$ potassium chloride, $1.5 \mathrm{mmol} / \mathrm{l}$ magnesium chloride, $200 \mu \mathrm{mol} / \mathrm{l}$ of each of the dNTPs, $1 \mu \mathrm{mol} / \mathrm{l}$ of primers specific for the human GnRH-I receptor mRNA (7) (forward primer: 5'-AGT CCA ATG GTA TGC TGG AG-3', backward primer: 5'-ACC CGT GTC AGG GTG AAG AT-3') or the human GnRH-II receptor-like mRNA (6) (forward primer: 5'-CTG GCT GTG GAC ATC GCA TGT-3', backward primer: 5'-ATG GCA GTC AGT GGC AGC AGA-3'), and 1.25 U AmpliTaq Gold polymerase (Applied Biosystems, Weiterstadt, Germany) in a Applied Biosystems DNA thermal cycler 9600. Thirty-five cycles of amplification of PCR were carried out: denaturation at $94^{\circ} \mathrm{C}$ for $30 \mathrm{~s}$, annealing at $60^{\circ} \mathrm{C}(\mathrm{GnRH}-\mathrm{I}$ receptor $)$ or $58^{\circ} \mathrm{C}(\mathrm{GnRH}-$ II receptor) for $60 \mathrm{~s}$, followed by extension at $72{ }^{\circ} \mathrm{C}$ for 60 s. The PCR products were separated by gel electrophoresis in $1.5 \%$ agarose and visualized by ethidium bromide staining on a u.v. transilluminator.

The complete and functional human GnRH-II receptor transcript still could not be identified, therefore the GnRH-II receptor mRNA was called 'GnRH-II receptorlike mRNA'.

\section{Restriction enzyme analysis}

The GnRH-I receptor PCR products were digested with the restriction endonucleases BamHI and PstI, under conditions recommended by the manufacturer (Roche Diagnostics). The digested products, along with untreated aliquots of each PCR sample, were then fractionated on $1 \%$ agarose gel and stained.

\section{Southern blot}

The GnRH-I receptor PCR products were separated on $1.5 \%$ agarose gels, visualized as described, and then transferred to Hybond-N ${ }^{+}$membranes (AmershamBuchler, Braunschweig, Germany). The blots were hybridized with a full-length cDNA (7) for the human GnRH-I receptor (bp 1-1560) with the enhanced chemiluminescence-direct nucleic acid labelling and detection system (RPN 300; Amersham-Buchler) according to the instructions of the manufacturer.

Southern blot analysis of the GnRH-II receptor PCR products was performed using a biotin-3'-endlabelled GnRH-II receptor probe designed according to a region (transmembrane domain III) highly conserved from fish (Morone saxatilis) to primates (Macaca mulatta): 5'CTG ATG TTC CTG AAA CTA ATG GCC ACG TAT TCT GCA GCT TTC-3' (6). The blots were prehybridized and hybridized in standard hybridization solution [50\% formamide, $5 \times \mathrm{SSPE}$ (containing $0.75 \mathrm{~mol} / \mathrm{l}$ $\mathrm{NaCl}, 0.05 \mathrm{~mol} / \mathrm{l} \mathrm{NaH} \mathrm{PO}_{4}$, and $5 \mathrm{mmol} / \mathrm{l} \mathrm{EDTA}$ at $\mathrm{pH}$ $7.4), \quad 5 \times$ Denhardt's, $0.5 \%$ SDS and $100 \mu \mathrm{g} / \mathrm{ml}$ 
denatured herring sperm DNA] at $42{ }^{\circ} \mathrm{C}$, followed by washing in high stringency conditions $(0.1 \times$ SSPE and $0.1 \%$ SDS at $65^{\circ} \mathrm{C}$ for $\left.10 \mathrm{~min}\right)$. Subsequently, the hybridized blots were visualized using the LightShift reagents according the manufacturer's instructions (Perbio Science, Rockfort, Illinois, USA).

\section{Proliferation assays}

The time-course and dose-response proliferation experiments were performed as described in detail previously $(2,3)$. Briefly, 20000 cells of each cell line were plated in four-well cluster dishes (Nunc, Roskilde, Denmark) and allowed to attach to the wells. After $24 \mathrm{~h}$, the medium was changed and $20 \mu \mathrm{l}$ PBS-BSA or appropriate dilutions of the GnRH-I agonist triptorelin or the GnRH-I antagonist cetrorelix were added, resulting in final concentrations of $10 \mathrm{pmol} / \mathrm{l}$ to $10 \mu \mathrm{mol} / \mathrm{l}$. Every $12 \mathrm{~h}$, fresh PBS-BSA or triptorelin or cetrorelix were added. After $24 \mathrm{~h}$ of incubation, the medium was changed. After 1, 2, 3 and 4 days, the cells were counted in a Neubauer haemocytometer $(2,3)$.

\section{GnRH-I receptor knockout experiments}

A 43 bp fragment of the human GnRH-I receptor cDNA was cloned in antisense orientation (5'-CT AGA ACC ATG GAC TGT CCG ACT TTG CTG TTG CTT TTC AAA GC-3') into the NheI/SalI sites of the eucaryotic expression vector, pIRES (Clontech, Palo Alto, California, USA), to produce the pGnRH-IR-antisense vector.

Cells were grown to approximately 50\% confluence on Nunc two-well chamber slides (immune cytochemistry), in Nunc four-well cluster dishes (proliferation assay) or in Nunc $100 \mathrm{~mm}$ dishes (immunoblotting). Transfections were done using Superfect liposome reagents and following the manufacturer's instructions (Qiagen). After $12 \mathrm{~h}$, transfected cells and non-transfected control cells were treated with the GnRH-I agonist triptorelin $(100 \mathrm{nmol} / \mathrm{l})$ to induce GnRH-I receptor protein internalization. Twelve hours later, the medium was changed and $20 \mu \mathrm{l}$ PBS-BSA or appropriate dilutions of triptorelin, the GnRH-I antagonist cetrorelix or GnRH-II were added, to a final concentration of $10 \mu \mathrm{mol} / \mathrm{l}$. Every $12 \mathrm{~h}$, fresh PBS-BSA or triptorelin or cetrorelix or GnRH-II was added. After $24 \mathrm{~h}$ of incubation, the medium was changed.

After 4 days of treatment, the cells grown on twowell chamber slides were fixed in $4 \%$ paraformaldehyde (PFA) at $4^{\circ} \mathrm{C}$ overnight. The cells were washed in PBS and then treated with $1 \mathrm{~mol} / \mathrm{l}$ glycine for blocking free aldehyde groups $(30 \mathrm{~min})$, washed in PBST $(0.2 \%$ BSA, $0.1 \%$ Triton X-100 in PBS) for $2 \times 15 \mathrm{~min}$, and treated in PBSTN (5\% FCS in PBST) for blocking further unspecific protein binding sites $(10 \mathrm{~min})$. The first antibody was a monoclonal mouse anti-human GnRH-I receptor (clone A9E4; Research Diagnostics, Flanders, New Jersey, USA), diluted 1:20 in PBSTN; the cells were incubated therein at $4^{\circ} \mathrm{C}$ overnight. After three careful washes in PBST, the cells were incubated with PBSTN for 30 min and then treated with the Histostain SP kit for mouse primary antibody (Zymed, San Francisco, California, USA) according the manufacturer's instructions. Dako (Carpinteria, California, USA) 3,3'-diaminobenzidine liquid substrate-chromogen system was used as substrate. Controls were performed by omission of the primary antibody.

After 1, 2, 3 and 4 days of treatment, the cells grown in $100 \mathrm{~mm}$ dishes were collected by centrifugation at $200 \boldsymbol{g}$ and washed twice with PBS-BSA. Aliquots were counted and then the cells were suspended and homogenized using an all-glass Potter homogenizer (Braun, Melsungen, Germany) in $10 \mathrm{mmol} / \mathrm{l}$ Tris $-\mathrm{HCl}$, pH 7.6, containing $2 \mathrm{~g} / \mathrm{l}$ BSA and $1 \mathrm{mmol} / \mathrm{l}$ dithiothreitol (DTT, Merck \& Co., Darmstadt, Germany). After nuclei and debris had been removed by centrifugation at $200 \boldsymbol{g}$, plasma membranes were collected at $70000 \boldsymbol{g}$. Aliquots of the membrane preparations, equivalent to $300000-$ 400000 cells, were resuspended in lysis buffer ( $1 \mathrm{mmol} / \mathrm{l}$ EGTA, $1 \mathrm{~mol} / \mathrm{l}$ DTT and $10 \mathrm{~mol} / \mathrm{l}$ Tris$\mathrm{HCl}, \mathrm{pH}$ 7.4). The membrane preparations were separated by SDS-PAGE $(7.5 \%)$ under reducing conditions, transferred to nitrocellulose membranes, blocked with 3\% BSA in PBST $(10 \mathrm{~mol} / \mathrm{l}$ Tris-HCl, $\mathrm{pH} 7.4$, $0.1 \%$ Tween 20 ) for $2 \mathrm{~h}$, incubated with polyclonal rabbit anti-human GnRH-I receptor antiserum (Peptide Research Laboratories, Heidelberg, Germany) in a 1:400 dilution in 1\% BSA in PBST for $1 \mathrm{~h}$ and then, after washings, incubated with horseradish peroxidase-conjugated goat anti-rabbit IgG in a 1:2000 dilution in 1\% BSA in PBST for $1 \mathrm{~h}$ (Sigma, Deisenhofen, Germany). After washings, specifically bound antibody was detected using the enhanced chemiluminescence kit (ECL; Amersham Pharmacia Biotech). Controls were performed by substitution of the primary antiserum by normal serum.

The cells grown in four-well cluster dishes were counted in a Neubauer haemocytometer after 4 days of treatment as described above.

\section{Statistical analysis}

All experiments were repeated three times with different passages of the respective cell lines. Data were tested for significant differences using the MannWhitney U-test. The data from the dose-response experiments were tested for significant differences by one-way analysis of variance followed by StudentNewman-Keuls' test for comparison of individual groups, after a Bartlett test had shown that variances were homogenous. 


\section{Results}

\section{Expression of GnRH-I receptors and GnRH-II receptor-like mRNA in endometrial and ovarian cancer cells}

PCR amplification of cDNA from the endometrial cancer cell lines Ishikawa, Hec-1A and Hec-1B and the ovarian cancer cell lines EFO-21, EFO-27, OVCAR-3 and BG-1 with the oligonucleotide primers for the human GnRH-I receptor yielded the expected $417 \mathrm{bp}$ product (Fig. 1A). Cleavage of the $417 \mathrm{bp}$ product with restriction enzymes yielded the expected fragments of $297 \mathrm{bp}$ and $114 \mathrm{bp}$ (PstI) and $232 \mathrm{bp}$ and $179 \mathrm{bp}$ (BamHI; data not shown). The sequence of the PCR products was further confirmed by Southern blot analysis using a full-length cDNA probe for the human GnRH-I receptor (Fig. 1B). Expression of GnRH-I receptor mRNA could not be detected in the ovarian cancer cell line SK-OV-3 (Fig. 1A, B).

Using oligonucleotide primers for a human GnRH-II receptor-like mRNA, the expected $337 \mathrm{bp}$ product was detected (Fig. 2A). As the complete and functional human GnRH-II receptor transcript still could not be identified, the GnRH-II receptor mRNA was called 'GnRH-II receptor-like mRNA'. Southern blot analysis using a biotin-labelled GnRH-II receptor-like probe confirmed the authenticity of the PCR products (Fig. 2A). All endometrial cancer cell lines and the ovarian cancer cell lines EFO-21, SK-OV-3, OVCAR-3 and BG1 showed GnRH-II receptor-like mRNA expression (Fig. 2A, B). However, we found a stop codon in this sequence (data not shown). The GnRH-II receptor-like mRNA was therefore suspected to be non-functional. In the ovarian cancer cell line EFO-27, GnRH-II receptor-like mRNA expression was absent (Fig. 2A, B).

\section{Effects of the GnRH-I agonist triptorelin, the GnRH-I antagonist cetrorelix and GnRH-II on cell proliferation}

In the GnRH-I receptor-positive ovarian cancer cell line EFO-21, the proliferation was dose-dependently
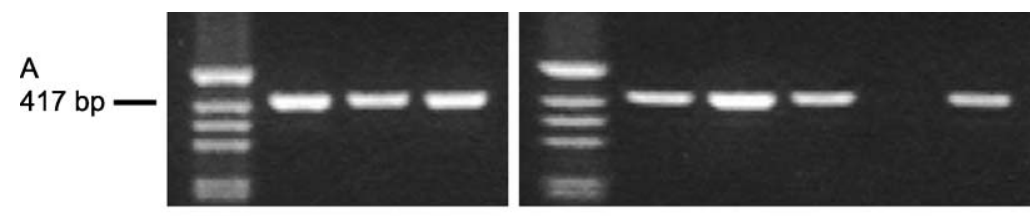

B $417 \mathrm{bp}-$

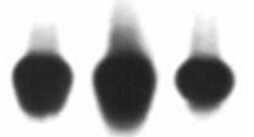

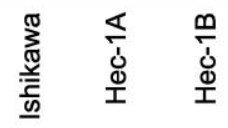

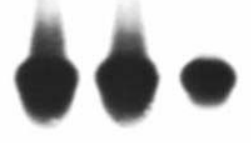

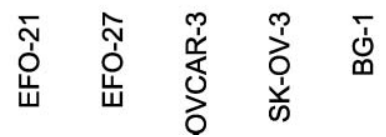

Figure 1 Expression of GnRH-I receptor mRNA in Ishikawa, Hec-1A and Hec-1B human endometrial cancer cell lines and in EFO-21, EFO-27, OVCAR-3, SK-OV-3 and BG-1 human ovarian cancer cell lines, (A) by RT-PCR using specific primers for human GnRH-I receptor and (B) by Southern blot using a full-length $\mathrm{GnRH}-\mathrm{I}$ receptor cDNA probe. GnRH-I receptor mRNA expression could be detected in all cell lines tested except for the human ovarian cancer cell line SK-OV-3. However, the GnRH-II receptor-like mRNA detected is suspected to be non-functional because of the stop codon in its sequence.

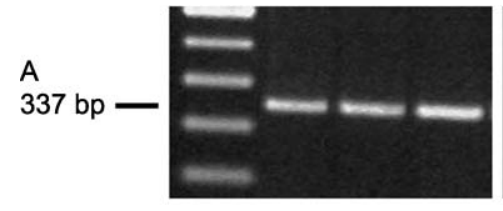

B 337 bp -
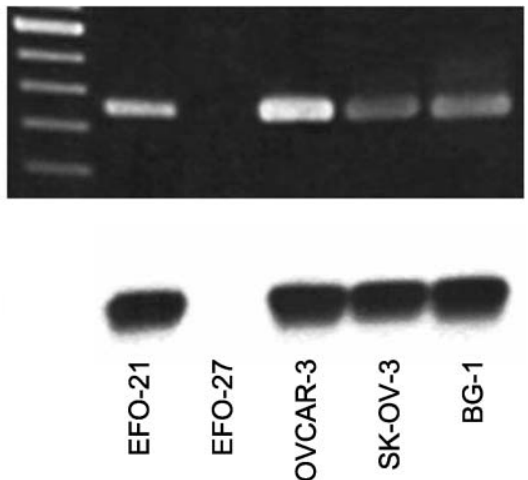

Figure 2 Expression of GnRH-II receptor-like mRNA in Ishikawa, Hec-1A and Hec-1B human endometrial cancer cell lines and in EFO21, EFO-27, OVCAR-3, SK-OV-3 and BG-1 human ovarian cancer cell lines, (A) by RT-PCR using specific primers for human GnRH-II receptor and (B) by Southern blot using a GnRH-II receptor cDNA probe. GnRH-II receptor-like mRNA expression could be detected in all cell lines tested except for the human ovarian cancer cell line EFO-27. 
inhibited by 4 days of treatment with different concentrations ( $10 \mathrm{pmol} / \mathrm{l}, 1 \mathrm{nmol} / \mathrm{l}, 100 \mathrm{nmol} / \mathrm{l}, 10 \mu \mathrm{mol} / \mathrm{l})$ of the GnRH-I agonist triptorelin (Fig. 3A). With $10 \mathrm{pmol} / \mathrm{l}$ triptorelin, a significant decrease in cell number to $84.1 \pm 3.5 \%(P<0.01)$ of the control $(=100 \%)$ was observed. With $1 \mathrm{nmol} / \mathrm{l}$ triptorelin, the cell number was reduced to $78.0 \pm 2.2 \%$ $(P<0.001)$ of control. At $100 \mathrm{nmol} / \mathrm{l}$, triptorelin had still greater antiproliferative effects $(70.8 \pm 2.9 \%$ of control; $P<0.001$ ), and its inhibitory effects were maximal at a concentration of $10 \mu \mathrm{mol} / \mathrm{l}(58.4 \pm 2.5 \%$ of control; $P<0.001)$. Similar dose-response relationships for the antiproliferative effects were observed
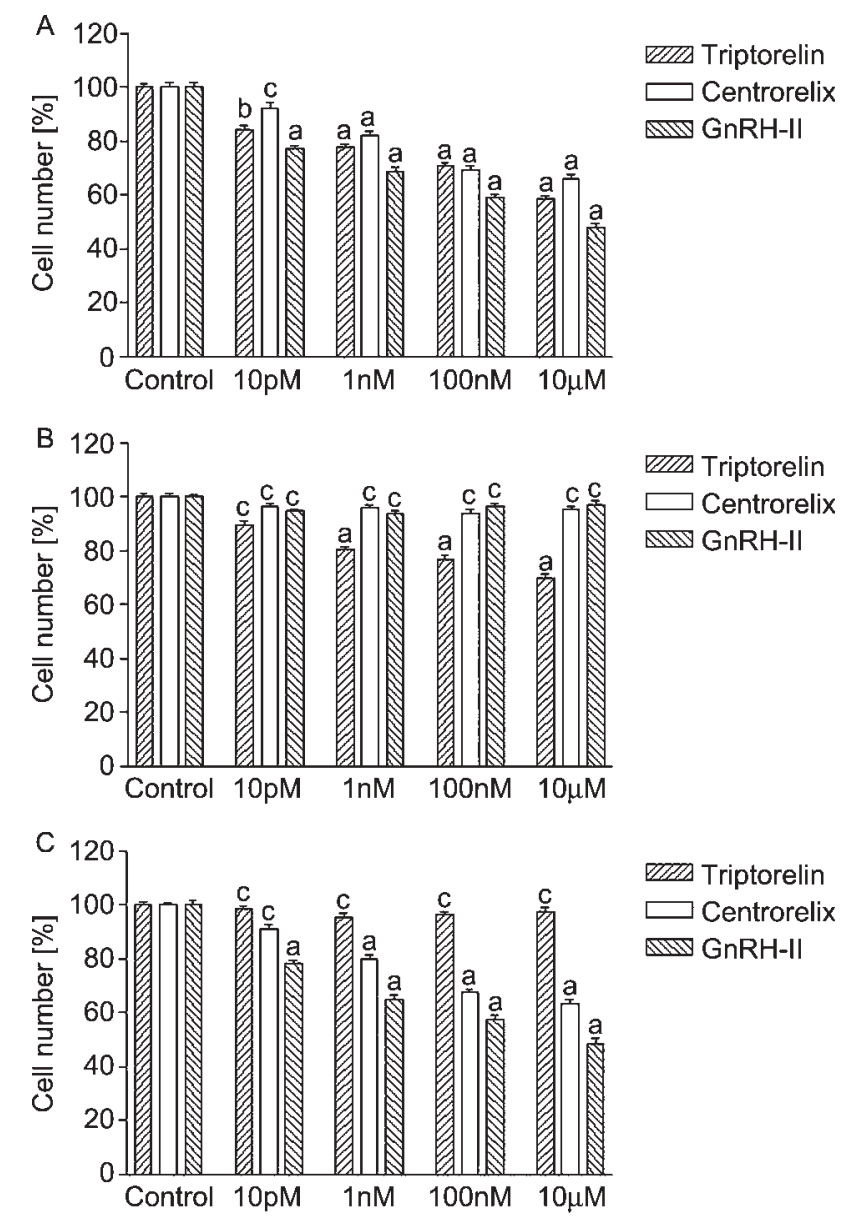

Figure 3 Effects of 4 days of treatment with increasing concentrations of the $\mathrm{GnRH}-\mathrm{I}$ agonist triptorelin, the $\mathrm{GnRH}-\mathrm{I}$ antagonist cetrorelix and $\mathrm{GnRH}-\mathrm{II}$ on the proliferation of (A) EFO-21, (B) EFO-27 and (C) SK-OV-3 human ovarian cancer cell lines. Cell number is expressed as a percentage of the controls (vehicle only: $100 \%$ ). The bars represent the means \pm S.E.M. of three independent experiments that were run in quadruplicate in three different passages of the respective cell line. a, $P<0.001$ compared with control; b, $P<0.01$ compared with control; c, not significantly different from control. Experiments using the human ovarian cancer cell lines OVCAR-3 and BG-1 and the human endometrial cancer cell lines Ishikawa, $\mathrm{Hec}-1 \mathrm{~A}$, and $\mathrm{Hec}-1 \mathrm{~B}$ gave results comparable to those obtained from the EFO-21 cell line $(A)$. with the GnRH-I antagonist cetrorelix and with GnRH-II (Fig. 3A). With $10 \mu \mathrm{mol} / \mathrm{l}$ of the GnRH-I antagonist cetrorelix, the cell number was reduced to $66.1 \pm 3.6 \%$ of control $(P<0.001)$ and with $10 \mu \mathrm{mol} / \mathrm{l} \mathrm{GnRH}-\mathrm{II}$ it was decreased to $47.8 \pm 3.7 \%$ of control $(P<0.001)$.

In the GnRH-I receptor-positive ovarian cancer cell line EFO-27, the proliferation was dose-dependently inhibited by 4 days of treatment with different concentrations of the GnRH-I agonist triptorelin (Fig. 3B). With $10 \mathrm{pmol} / \mathrm{l}$ triptorelin, only a slight decrease in cell number, to $89.4 \pm 3.5 \%$ (not significant) of the control $(=100 \%)$, was observed. With $1 \mathrm{nmol} / \mathrm{l}$ triptorelin, the cell number was $80.3 \pm 2.8 \%$ of control $(P<0.001)$; with $100 \mathrm{nmol} / \mathrm{l}$ triptorelin it was reduced to $76.8 \pm 2.9 \%$ of control $(P<0.001)$, and the inhibitory effects were maximal with a concentration of $10 \mu \mathrm{mol} / \mathrm{l}$ triptorelin $\quad(69.7 \pm 3.1 \%$ of control; $P<0.001)$. In contrast to findings for the EFO-21 cancer cell line, no relevant antiproliferative effects were observed with the GnRH-I antagonist cetrorelix or with GnRH-II (Fig. 3B).

In the GnRH-I receptor-negative ovarian cancer cell line SK-OV-3, we did not observe antiproliferative effects of the GnRH-I agonist triptorelin (Fig. 3C). However, using the GnRH-I antagonist cetrorelix or GnRH-II, the proliferation was dose-dependently inhibited by 4 days of treatment (Fig. 3C). With $10 \mathrm{pmol} / \mathrm{l}$ cetrorelix, only a slight decrease in cell number, to $91.3 \pm 3.5 \%$ (not significant) of the control ( = 100\%), was observed. With $1 \mathrm{nmol} / \mathrm{l}$ cetrorelix, the cell number was reduced to $79.8 \pm 3.9 \%$ of control $(P<0.001)$, with $100 \mathrm{nmol} / \mathrm{l}$ it was reduced to $67.5 \pm 3.1 \%$ of control $(P<0.001)$, and the inhibitory effects were maximal with a concentration of $10 \mu \mathrm{mol} / \mathrm{l}$ cetrorelix $(63.4 \pm 3.7 \%$ of control; $P<0.001)$. With $10 \mu \mathrm{mol} / \mathrm{l} \mathrm{GnRH}-\mathrm{II}$, the cell number was reduced to $48.8 \pm 4.1 \%$ of control $(P<0.001)$.

The proliferation data for the ovarian cancer cell lines OVCAR-3 and BG-1 (Table 1) and the endometrial cancer cell lines Ishikawa, Hec-1A and Hec-1B (Table 1) were identical with the data obtained from the ovarian cancer cell line EFO-21 (Fig. 3A).

\section{GnRH-I receptor knockout}

A 43 bp cDNA encoding a fragment of the human GnRH-I receptor was cloned in antisense orientation into the NheI/SalI sites of the eucaryotic expression vector pIRES, to produce the pGnRH-I-R-antisense vector (Fig 4).

Knockout of the GnRH-I receptor protein was controlled by immune cytochemistry using a monoclonal mouse anti-human GnRH-I receptor antibody (Fig. 5) and immunoblotting using a polyclonal rabbit antihuman GnRH-I receptor antiserum (Fig. 6). After internalization of the GnRH-I receptor induced by the GnRH-I agonist triptorelin, a high density of novel 
Table 1 Antiproliferative effects of the $\mathrm{GnRH}-\mathrm{I}$ agonist triptorelin $(10 \mu \mathrm{mol} / \mathrm{l})$, the $\mathrm{GnRH}-\mathrm{I}$ antagonist cetrorelix $(10 \mu \mathrm{mol} / \mathrm{l})$ and $\mathrm{GnRH}-\mathrm{II}(10 \mu \mathrm{mol} / \mathrm{I})$ on Ishikawa, Hec-1A and Hec-1B human endometrial cancer cell lines and EFO-21, EFO-27, OVCAR-3, SK-OV-3 and BG-1 human ovarian cancer cell lines. Cell numbers are expressed as mean \pm S.E.M. percentages of the controls (vehicle only: 100\%).

\begin{tabular}{llll}
\hline \multicolumn{3}{c}{ Cell number (\% of control) } \\
\cline { 2 - 4 } Cell line & Triptorelin & Cetrorelix & GnRH-II \\
\hline Endometrial cancer cell lines & & \\
Ishikawa & $63.0 \pm 1.8$ & $69.7 \pm 2.2$ & $49.2 \pm 5.7$ \\
Hec-1A & $64.9 \pm 4.4$ & $70.1 \pm 2.5$ & $44.1 \pm 4.3$ \\
Hec-1B & $76.9 \pm 16.9$ & $59.2 \pm 2.3$ & $52.4 \pm 6.5$ \\
Ovarian cancer cell lines & & \\
EFO-21 & $58.4 \pm 2.5$ & $66.1 \pm 3.6$ & $47.8 \pm 3.7$ \\
EFO-27 & $69.7 \pm 3.1$ & $95.3 \pm 2.0$ & $97.0 \pm 2.8$ \\
SK-OV-3 & $97.7 \pm 3.5$ & $63.4 \pm 3.7$ & $48.8 \pm 4.1$ \\
OVCAR-3 & $71.6 \pm 3.8$ & $63.4 \pm 1.8$ & $38.5 \pm 6.6$ \\
BG-1 & $70.8 \pm 1.5$ & $67.1 \pm 3.2$ & $51.2 \pm 4.9$ \\
\hline
\end{tabular}

Values in bold italics indicate no antiproliferative effect; all other values represent significant $(P<0.001)$ antiproliferative effects.

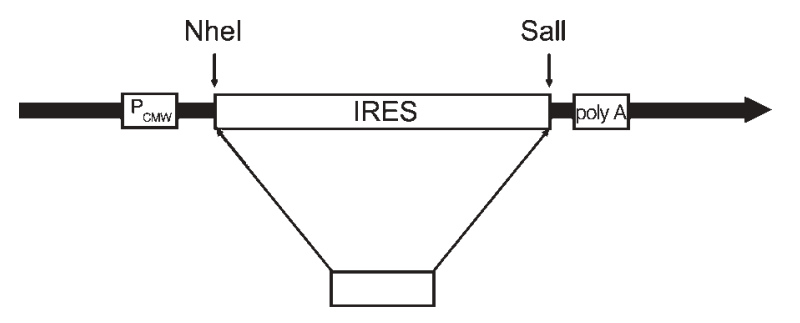

GnRH-I R antisense

Figure 4 Schematic representation of $p G n R H-I-R$-antisense expression vector. A $43 \mathrm{bp}$ cDNA encoding a fragment of the human $\mathrm{GnRH}-\mathrm{I}$ receptor was cloned in antisense orientation into the Nhel/Sall sites of the eucaryotic expression vector pIRES.

synthesis of GnRH-I receptor protein, seen as GnRH-I receptor antigenicity, could be observed in non-transfected cells (Fig. 5A), whereas transfected cells showed only slight GnRH-I receptor antigenicity (Fig. 5B). In controls performed by omission of the primary antibody, no GnRH-I receptor antigenicity was observed (Fig. 5C). As early as 1 day after knockout of GnRH-I receptor expression, GnRH-I receptor protein antigenicity was significantly reduced in comparison with the control (Fig. 6). After 2 and 4 days, no more GnRH-I receptor protein could be detected (Fig. 6); however, 2 days later a slight GnRH-I receptor protein antigenicity could be observed (not shown), indicating that the effectiveness of GnRH-I receptor knockout begins to decrease after 6 days.

\section{Effects of GnRH-I receptor knockout on the antiproliferative activity of the GnRH-I agonist triptorelin the GnRH-I antagonist cetrorelix and of GnRH-II}

After knockout of the GnRH-I receptor, the antiproliferative effects of the GnRH-I agonist triptorelin on endometrial and ovarian cancer cells were abrogated, whereas the growth inhibitory effects of the GnRH-I antagonist cetrorelix were still the same as observed in non-transfected cancer cells.

After 4 days of treatment of GnRH-I receptor knockout cell lines with cetrorelix $(10 \mu \mathrm{mol} / \mathrm{l})$ the observed cell numbers, expressed as \% of control $(=100 \%)$ were: Hec-1A (Fig. 7A) 41.99 $\pm 7.17 \%$ of control $(P<0.001)$; Ishikawa (Fig. 7B) $33.20 \pm 3.52 \%$ of control $(P<0.001)$; EFO-21 (Fig. 7C) 34.35 $23.44 \%$ of control $(P<0.001)$; OVCAR-3 (Fig. 7D) 30.92 $4.39 \%$ of control $(P<0.001)$.

Treatment of GnRH-I receptor knockout cell lines for 4 days with the GnRH-I agonist triptorelin $(10 \mu \mathrm{mol} / \mathrm{l})$ resulted in cell numbers, expressed as \% of control $(=100 \%$ ), as follows: Hec-1A (Fig. 7A) 94.14士 $9.96 \%$ of control (not significant); Ishikawa (Fig. 7B) $84.50 \pm 8.20 \%$ of control (not significant); EFO-21 (Fig. 7C) $83.97 \pm 8.94 \%$ of control (not significant); OVCAR-3 (Fig. 7D) 89.12 $\pm 7.44 \%$ of control (not significant)

After 4 days of treatment of GnRH-I receptor knockout cell lines with GnRH-II $(10 \mu \mathrm{mol} / \mathrm{l})$ the observed cell numbers, expressed as \% of control $(=100 \%)$, were: Hec-1A (Fig. 7A) $40.51 \pm 5.06 \%$ of control $(P<0.001)$; Ishikawa (Fig. 7B) 30.81 $44.74 \%$ of control $(P<0.001)$; EFO-21 (Fig. 7C) 32.10土3.58\% of control $(P<0.001)$; OVCAR-3 (Fig. 7D) 31.61士 $5.63 \%$ of control $(P<0.001)$.
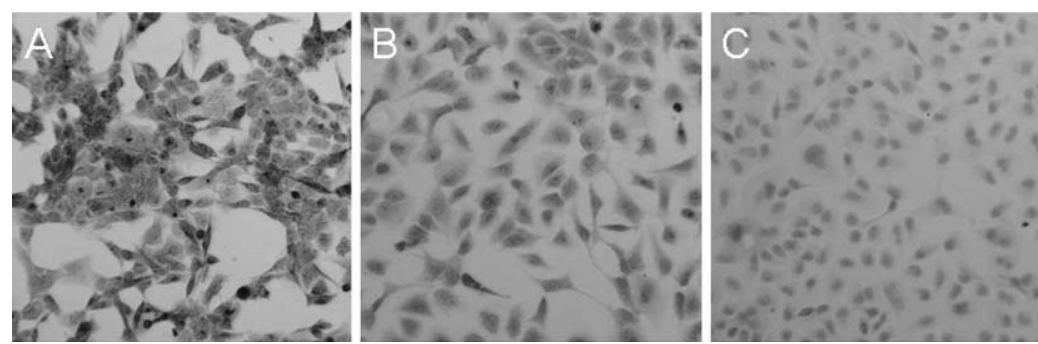

Figure 5 Immune histochemical detection of GnRH-I receptor protein in EFO-21 human ovarian cancer cells grown on two-well chamber slides using a monoclonal mouse anti-human GnRH-I receptor antibody. (A) Non-transfected cells. (B) Cells transfected with pGnRH-I-R antisense expression vector. (C) Control performed by omission of the primary antibody. Experiments using the human endometrial cancer cell lines Ishikawa and Hec-1A and the human ovarian cancer cell line OVCAR-3 gave identical results. 


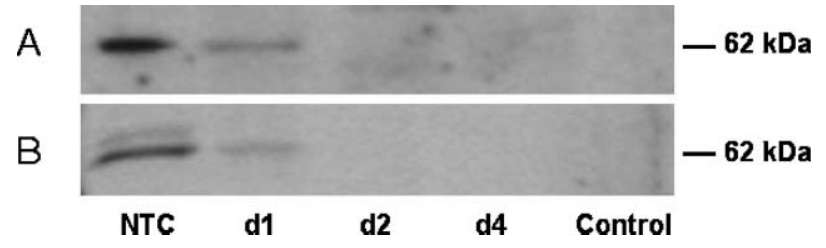

Figure 6 Immunoblotting of $\mathrm{GnRH}-\mathrm{I}$ receptor protein in $(\mathrm{A})$ Ishikawa human endometrial cancer cells and (B) EFO-21 human ovarian cancer cells using a polyclonal rabbit anti-human $\mathrm{GnRH}-\mathrm{I}$ receptor antiserum. NTC, non-transfected cells; d1, d2, d4, cells 1,2 or 4 days after transfection with pGnRH-I-R antisense expression vector. Control performed by substitution of the primary antiserum by normal serum. Experiments using the human endometrial cancer cell line $\mathrm{Hec}-1 \mathrm{~A}$ and the human ovarian cancer cell line OVCAR-3 gave comparable results.
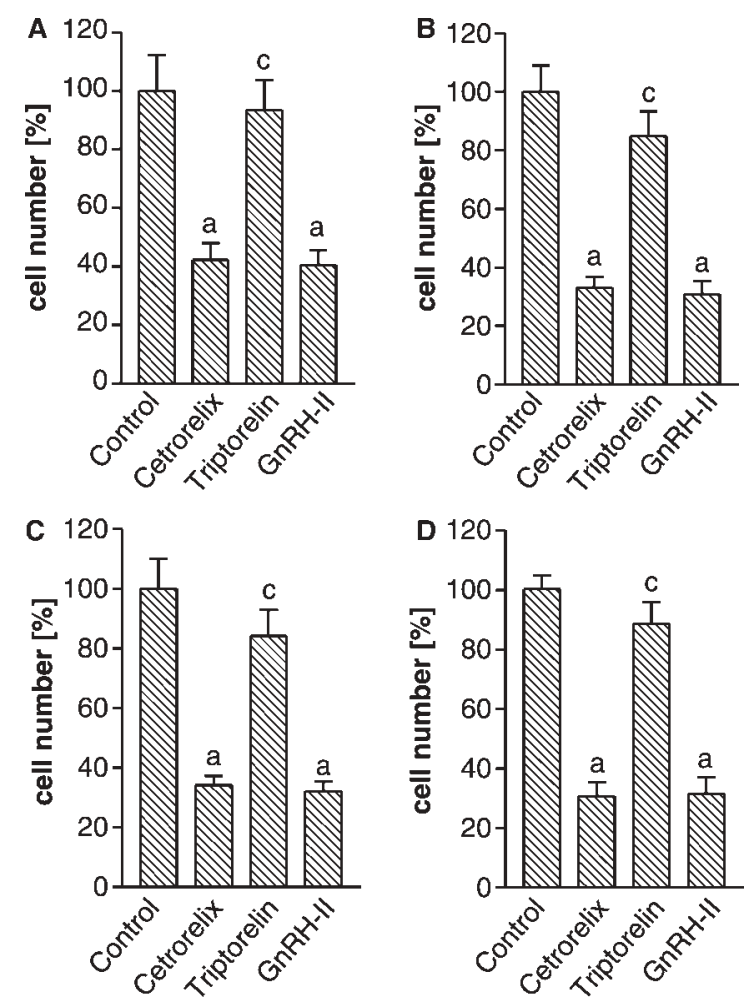

Figure 7 Effects of 4 days of treatment with the $\mathrm{GnRH}$-I agonist triptorelin $(10 \mu \mathrm{mol} / \mathrm{I})$, the $\mathrm{GnRH}-\mathrm{I}$ antagonist cetrorelix $(10 \mu \mathrm{mol} / \mathrm{I})$ and $\mathrm{GnRH}-\mathrm{II}(10 \mu \mathrm{mol} / \mathrm{l})$ on the proliferation of $(\mathrm{A}) \mathrm{Hec}-1 \mathrm{~A}$ and $(\mathrm{B})$ Ishikawa human endometrial cancer cell lines, and (C) EFO-21 and (D) OVCAR-3 human ovarian cancer cell lines after knockout of $\mathrm{GnRH}-\mathrm{I}$ receptor protein expression. Cell number is expressed as a percentage of the controls (vehicle only: 100\%). The bars represent the means \pm S.E.M. of three independent experiments that were run in quadruplicate in three different passages of the respective cell line. a, $P<0.001$ compared with control; c, not significantly different from control.

\section{Discussion}

We have previously demonstrated that, in human endometrial and ovarian cancer cell lines, the GnRH-I antagonist cetrorelix has antiproliferative effects comparable to those of GnRH-I agonists, indicating that the dichotomy of GnRH-I agonists and antagonists might not apply to the GnRH-I system in these cells $(2,3)$. In endometrial cancer cell lines Hec-1A and Ishikawa, similar dose-dependent antiproliferative effects of both the GnRH-I agonist triptorelin and the GnRH-I antagonist cetrorelix were found (3). In the EFO-21 ovarian cancer cell line, the GnRH-I antagonists cetrorelix and ramorelix produced dose-dependent antiproliferative effects similar to those of the GnRH-I agonist triptorelin (2). In contrast, in the EFO-27 ovarian cancer cell line neither cetrorelix nor ramorelix had any effect on the proliferation of the cells, even at the high concentration of $10 \mu \mathrm{mol} / \mathrm{l}$, whereas the GnRH-I agonist triptorelin exhibited dose-dependent antiproliferative effects (2). During simultaneous treatment, cetrorelix partly antagonized the antiproliferative effects of $1 \mathrm{nmol} / \mathrm{l}$ to $10 \mu \mathrm{mol} / \mathrm{l}$ concentrations of triptorelin, and thus acted like an antagonist in the EFO27 cell line (2). Until now it has not been understood why GnRH-I antagonists had antiproliferative effects in endometrial and ovarian cancer cell lines, with the exception of the ovarian cancer cell line EFO-27.

In this study we were able to show that, in endometrial and ovarian cancer cells affected by both the GnRH-I agonist triptorelin and the GnRH-I antagonist cetrorelix $(2,3)$, GnRH-II also showed highly effective antiproliferative effects. In contrast, in the EFO-27 ovarian cancer cell line in which the GnRHI antagonist cetrorelix had no such effects (2), GnRH-II was also not effective. In this cell line, cetrorelix had effects like those of a true GnRH-I antagonist: it partly antagonized the antiproliferative effects of the GnRH-I agonist triptorelin (2). In the ovarian cancer cell line SK-OV-3, which does not express GnRH-I receptors (7), the GnRH-I agonist triptorelin had no effects on cell proliferation (7), whereas the GnRH-I antagonist cetrorelix and GnRH-II (6) had strong antiproliferative effects.

In cell lines affected by both the GnRH-I agonist triptorelin and the GnRH-I antagonist cetrorelix, the effects of the former were abrogated after GnRH-I receptor knockout, whereas those of cetrorelix and of GnRH-II persisted. These findings suggest that, in endometrial and ovarian cancer cells, the antiproliferative effects of the GnRH-I antagonist cetrorelix and of GnRH-II are not mediated through the GnRH-I receptor.

Several groups have tried to find a functional human GnRH-II receptor (9-12). Until now, attempts to clone and sequence of a full-length human GnRH-II receptor have not been successful (13). Morgan et al. (14) found that the human GnRH-II receptor is expressed as a variety of splice variants and a functional human GnRH-II receptor transcript was not found. The GnRH-II receptor-like mRNA detected in this and in our previous study (6) is suspected to be non-functional because of the stop codon in the sequence. Thus further investigations are required to identify the receptor that mediates the activities of the GnRH-I antagonist 
cetrorelix and of GnRH-II and to elucidate the entire mechanism of these effects.

Nevertheless, our above-mentioned data suggest that, in human endometrial and ovarian cancer cells in addition to the GnRH-I receptor, an additional functional receptor may be present, mediating the antiproliferative effects of the GnRH-I antagonist cetrorelix and GnRH-II. At present, the functional role of a putative additional receptor for GnRH co-expressed with GnRH-I receptor in human endometrial and ovarian cancer cells is unknown. As GnRH-II has strong antiproliferative effects without involving the induction of apoptosis (6), it could be speculated that the additional receptor interacts with pathways regulating the cell cycle. It is well established that GnRH-I and its receptor in human endometrial and ovarian cancers are parts of a negative autocrine mechanism of cell proliferation ( 1 , $5,15,16)$ and that GnRH-I protects the cells against apoptosis (17). Co-expression of the GnRH-I receptor and an additional receptor for GnRH in human endometrial and ovarian cancer cells suggests a potential interaction between these two receptor types. Moreover, after knockout of the GnRH-I receptor, the antiproliferative effects of the GnRH-I antagonist cetrorelix seemed to be increased. We do not have any explanation for this effect at present, but it seems reasonable to speculate that, in cells in which the GnRH-I receptor and a putative additional receptor for GnRH are coexpressed, a cross-talk between the signalling of both receptors might take place. It would be very interesting to know whether or not the antiproliferative effects of the GnRH-I antagonist cetrorelix and GnRH-II would be abrogated after knockout of the putative additional receptor for GnRH. However, different knockout experiments using GnRH-II receptor antisense fragments resulted in apoptotic cell death (unpublished results). At present, therefore, this question cannot be answered.

In conclusion, our present data suggest that, in endometrial and ovarian cancer cells, the antiproliferative effects of the GnRH-I antagonist cetrorelix are not mediated through the GnRH-I receptor. If there is a functional additional receptor for GnRH, the GnRH-I antagonist cetrorelix may act as an agonist on this receptor. This could rationalize the paradox of similar effects of GnRH-I agonists and antagonists on tumour cell proliferation.

\section{Acknowledgements}

We thank Dr Robert P. Millar, Medical Research Council, Human Reproductive Sciences Unit, Edinburgh, Scotland, for the gift of the oligonucleotide primers for the human GnRH-II receptor. We are grateful to Zentaris (Frankfurt, Germany) for supplying the GnRH-I antagonist cetrorelix (SB-75) and to Ferring Pharmaceuticals (Copenhagen, Denmark) for the gift of the GnRH-I agonist triptorelin. We thank Renate Dietrich, Matthias Läsche and Hiltrud Schulz for excellent technical assistance. This work was supported by the German-Israeli Foundation for Scientific Research and Development (Grant No. I-684$176.2 / 2000$ to $\mathrm{G}$ Emons) and by the Deutsche Forschungsgemeinschaft (Grant No. GR 1895/2-1 to C Gründker).

\section{References}

1 Gründker C, Günthert AR, Westphalen S \& Emons G. Biology of the gonadotropin-releasing hormone (GnRH) system in gynecological cancers. European Journal of Endocrinology 2002146 1-14.

2 Emons G, Ortmann O, Becker M, Irmer G, Springer B, Laun R, Holzel F, Schulz KD \& Schally AV. High affinity binding and direct antiproliferative effects of LHRH analogues in human ovarian cancer cell lines. Cancer Research $1993 \mathbf{5 4} 5439$-5446.

3 Emons G, Schröder B, Ortmann O, Westphalen S, Schulz KD \& Schally AV. High affinity binding and direct antiproliferative effects of luteinizing hormone-releasing hormone analogs in human endometrial cancer cell lines. Journal of Clinical Endocrinology and Metabolism 199377 1458-1464.

4 Irmer G, Bürger C, Müller R, Ortmann O, Peter U, Kakar SS, Neill JD, Schulz KD \& Emons G. Expression of the messenger RNAs for luteinizing hormone-releasing hormone (LHRH) and its receptor in human ovarian epithelial carcinoma. Cancer Research $199555817-822$.

5 Emons G, Ortmann O, Schulz KD \& Schally AV. Growth-inhibitory actions of luteinizing hormone releasing hormone on tumor cells. Trends in Endocrinology and Metabolism 19978 355-362.

6 Gründker C, Günthert AR, Millar RP \& Emons G. Expression of gonadotropin-releasing hormone II (GnRH-II) receptor in human endometrial and ovarian cancer cells and effects of GnRH-II on tumor cell proliferation. Journal of Clinical Endocrinology and Metabolism 200287 1427-1430.

7 Völker P, Gründker C, Schmidt O, Schulz KD \& Emons G. Expression of receptors for luteinizing hormone-releasing hormone in human ovarian and endometrial cancers: frequency, autoregulation and correlation with direct antiproliferative activity of LHRH analogues. American Journal of Obstetrics and Gynecology $2002 \mathbf{1 8 6} 171-179$.

8 Choi KC, Auersperg N \& Leung PCK. Expression and anti-proliferative effect of a second form of gonadotropin-releasing hormone in normal and neoplastic ovarian surface epithelial cells. Journal of Clinical Endocrinology and Metabolism 2001 86 5075-5078.

9 Millar R, Lowe S, Conklin D, Pawson A, Maudsley S, Troskie B, Ott T, Millar M, Lincoln G, Sellar R, Faurholm B, Scobie G, Kuestner R, Terasawa E \& Katz A. A novel mammalian receptor for the evolutionarily conserved type II GnRH. PNAS 200198 9636-9641.

10 Millar RP, Conklin D, Lofton-Day C, Hutchinson E, Troskie B, Illing N, Sealfon SC \& Hapgood J. A novel human GnRH receptor homolog gene: abundant and wide tissue distribution of the antisense transcript. Journal of Endocrinology 1999162 117-126.

11 Neill JD, Duck LW, Sellers JC \& Musgrove LC. A gonadotropinreleasing hormone (GnRH) receptor specific for GnRH II in primates. Biochemical and Biophysical Research Communications $20012821012-1018$.

12 Neill JD. GnRH and GnRH receptor genes in the human genome. Endocrinology $2002143737-743$.

13 Millar RP. GnRH II and type II GnRH receptors. Trends in Endocrinology and Metabolism 200314 35-43.

14 Morgan K, Conklin D, Pawson AJ, Sellar R, Ott TR \& Millar RP. A transcriptionally active human type II gonadotropin-releasing hormone receptor gene homolog overlaps two genes in the 
antisense orientation on chromosome 1q.12. Endocrinology 2003 $144423-436$.

15 Emons G, Weiß S, Ortmann O, Gründker C \& Schulz KD. Luteinizing hormone releasing hormone (LHRH) acts as a negative autocrine regulator of proliferation of human ovarian cancer. European Journal of Endocrinology 2000142 665-670.

16 Gründker C, Völker P \& Emons G. Antiproliferative signaling of LHRH in human endometrial and ovarian cancer cells through G-protein $\alpha \mathrm{i}$-mediated activation of phosphotyrosine phosphatase. Endocrinology 2001142 2369-2380.
17 Gründker C, Schulz K, Günthert AR \& Emons G. Luteinizing hormone-releasing hormone induces nuclear factor $\kappa \mathrm{B}$-activation and inhibits apoptosis in ovarian cancer cells. Journal of Clinical Endocrinology and Metabolism 200085 3815-3820.

Received 24 November 2003

Accepted 7 April 2004 